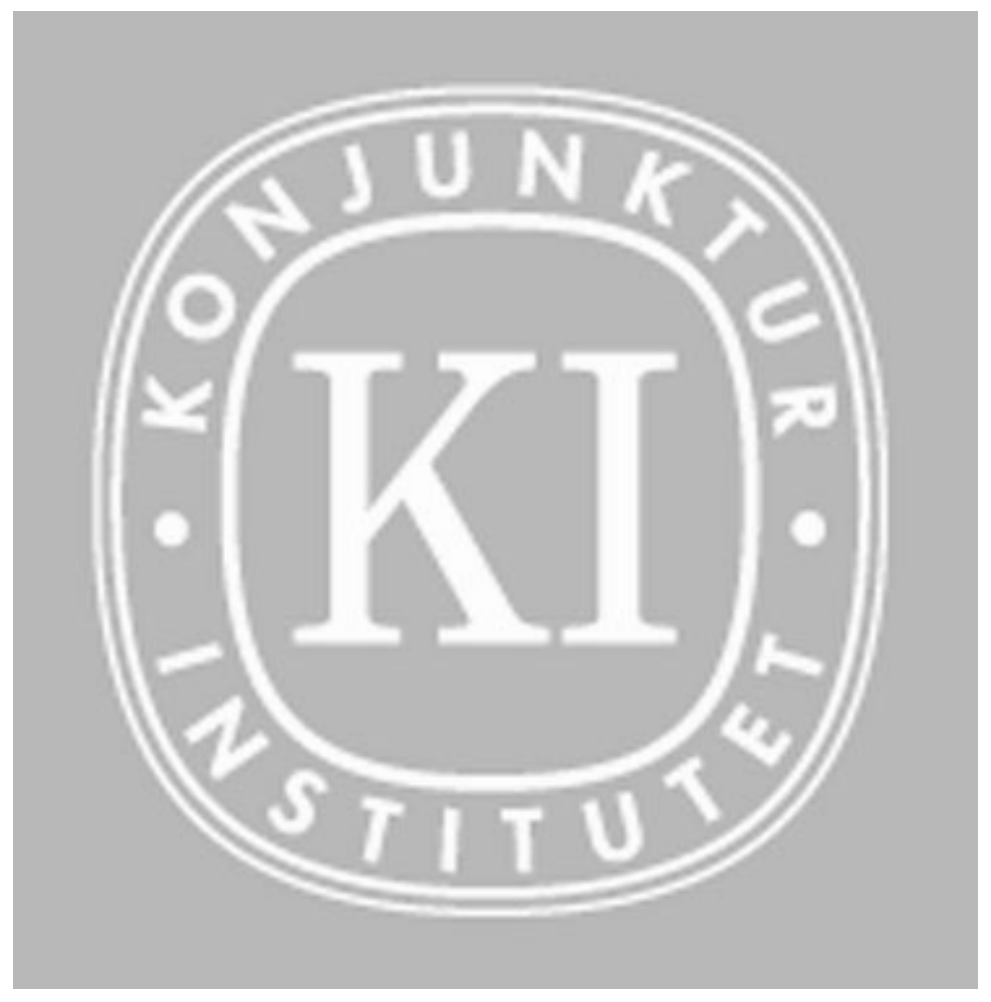

\title{
Making Climate Policy Efficient \\ Implementing a Model for Environmental Policy Efficiency
}

Sven Ove Hansson, Karin Edvardsson Björnberg and

Maria Vredin Johansson 
NI ER prepares analyses and forecasts of the Swedish and international economy and conducts related research. NIER is a government agency accountable to the Ministry of Finance and is financed largely by Swedish government funds. Like other government agencies, NI ER has an independent status and is responsible for the assessments that it publishes.

The Working Paper series consists of publications of research reports and other detailed analyses. The reports may concern macroeconomic issues related to the forecasts of the institute, research in environmental economics, or problems of economic and statistical methods. Some of these reports are published in their final form in this series, whereas others are previews of articles that are subsequently published in international scholarly journals under the heading of Reprints. Reports in both of these series can be ordered free of charge. Most publications can also be downloaded directly from the NI ER home page. 


\section{Sammanfattning}

Ett miljöpolitiskt styrmedels effektivitet, det vill säga dess förmåga att nå uppsatta mål, beror på en mängd olika faktorer. Även om vissa styrmedel, framförallt ekonomiska, har studerats relativt ingående saknas fortfarande kunskap om varför önskvärda effekter ibland uteblir. Det är därför viktigt att analysera hur miljöpolitiska styrmedel kan utformas och genomföras för att bli så effektiva som möjligt. I den här rapporten föreslår vi ett ramverk, en "styrmedelscykel", för att analysera och förbättra miljöpolitiska styrmedels effektivitet. Vi beskriver styrmedelscykeln element för element. Med exempel hämtade från det klimatpolitiska området identifierar vi områden som är intressanta för fortsatt forskning.

Att genomföra miljöpolitiska åtgärder är svårt. Det faktum att styrmedlen till övervägande del ska genomföras av de aktörer, företag, organisationer och enskilda, som själva utgör en del av problemet gör det ännu svårare. Myndigheter och departement (som till exempel Naturvårdsverket och Miljödepartementet) har centrala roller i utarbetandet av strategier och metoder för att genomföra, följa upp och utvärdera olika miljöpolitiska styrmedel. Förmågan att prioritera och välja vilken metod som bäst kan förmå andra aktörer att förändra sitt beteende är avgörande för hur framgångsrik miljöpolitiken blir. Ansvariga myndigheters och departements prioriteringar bör därför vara välgrundade och bygga på kunskap om olika styrmedels effektivitet (förmåga att nå uppsatta mål). Först då kan varje enskilt miljöproblem angripas genom en välbalanserad sammansättning av olika styrmedel till exempel skatter, subventioner, lagstiftning och information.

Hur effektivt ett styrmedel är beror på en mängd faktorer. Till exempel vilken målgrupp det riktar sig mot och vilka andra styrmedel som finns på det aktuella, eller näraliggande, politikområdet. Även om vissa ekonomiska styrmedel har studerats både teoretiskt och empiriskt finns fortfarande kunskapsluckor om när och varför önskvärda effekter uppstår eller uteblir. Vilka styrmedel eller vilka kombinationer av styrmedel som ger högst måluppfyllelse är därför en fråga av stort intresse.

I den här rapporten försöker vi belysa frågan: Hur ska miljöpolitiska styrmedel utformas och genomföras för att bli så effektiva som möjligt? 


\section{STYRMEDELSCYKELN}

I den här rapporten föreslår vi ett ramverk, en styrmedelscykel, för att studera miljöpolitisk effektivitet. Styrmedelscykeln består av sex olika element (se figuren nedan). Genom upprepa hela eller delar av cykeln är tanken att miljöpolitiken kan bli effektivare.

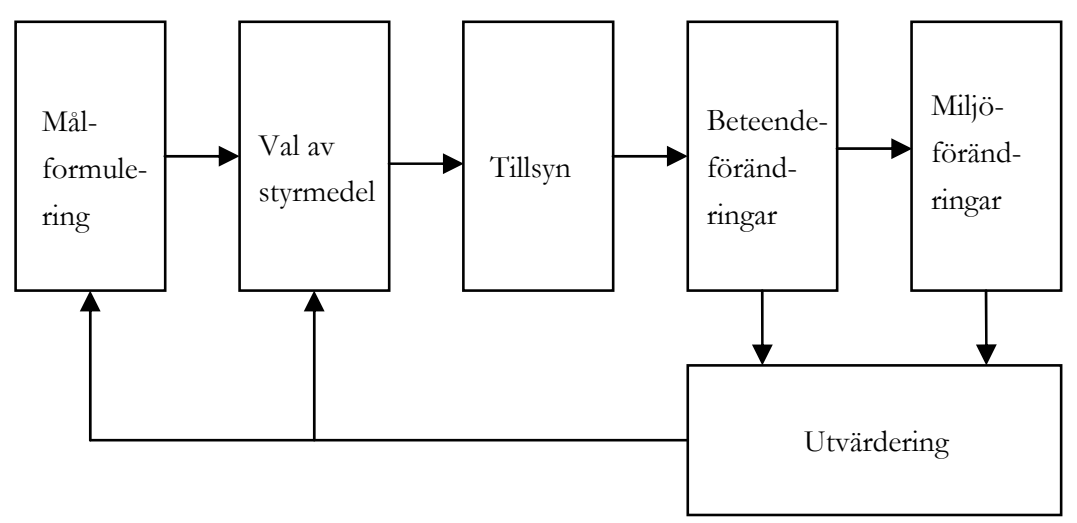

Styrmedelscykelns delar består av:

\section{- Målformulering}

Innebär att uppföljningsbara mål för miljötillstånd eller utsläpp formuleras (till exempel gränsvärden för koldioxid). Ett vanligt förekommande tillvägagångssätt vid målformulering är att formulera mål som är specifika, mätbara, accepterade, realistiska och tidsbestämda (sammanfattas ofta med akronymen SMART). I Sverige finns sexton miljökvalitetsmål som ligger till grund för den nationella miljöpolitiken.

\section{- Val av styrmedel}

Styrmedel kan vara frivilliga, som information, eller bindande, som legala och ekonomiska styrmedel. En tumregel är att använda legala styrmedel som regleringar och gränsvärden när samhällets kostnad för att inte uppnå miljömålet är hög (till exempel när det gäller mycket giftiga ämnen). När samhällets kostnad för att inte uppnå målet är lägre kan man istället använda ekonomiska styrmedel.

\section{- Tillsyn}

Efterlevnaden av regleringar och ekonomiska styrmedel måste kontrolleras. För regleringar kan inspektioner användas medan ekonomiska styrmedel måste kontrolleras genom jämförelser mellan olika typer av registerinformation (uppgifter om till exempel inköp av olja matchas mot antal utsläppsrätter). 


\section{- Beteendeförändringar}

Högre skatter eller regleringar som fastställer vilken teknologi som måste användas leder till att företag, organisationer och enskilda ändrar sina beteenden. I fallet med regleringar kan man förenklat säga att beteendeförändringarna innebär att det uppsatta miljömålet nås medan kostnaden för att nå målet inte är känd i förväg. I fallet med ekonomiska styrmedel är det tvärtom, kostnaden är känd men det uppsatta miljömålet nås inte med lika stor precision. Är skatten för lågt satt förändras beteenden mindre än vad som behövs och är den för högt satt förändras de mer än vad som behövs.

\section{- Milöförändringar}

En önskvärd effekt på miljöproblemet i fråga är det som alla miljöpolitiska styrmedel strävar efter att uppnå, men det är ofta svårt att fastställa effekten empiriskt. Miljöproblem uppstår ofta under lång tid och miljön behöver ofta lång tid för återhämtning.

\section{- Utvärdering}

Utvärdering av hur miljöpolitiken fungerar är viktigt för att inte samhällets resurser ska användas slösaktigt. Trots växande utgifter för miljöpolitiska åtgärder, ägnas relativt liten möda åt att utvärdera vilka effekter åtgärderna uppnår. Förklaringarna är flera. Eftersom miljöproblemen är komplexa är det till exempel svårt att fastställa orsakssamband och kontrollera för sammanblandningseffekter. Det kan därför vara lättare att utvärdera vad en viss åtgärd (höjd koldioxidskatt) leder till genom beteendeförändringar (minskad konsumtion av bensin, lägre utsläpp av koldioxid) än att fastställa åtgärdens effekt på miljön (minskad växthuseffekt).

I rapporten går vi igenom styrmedelscykeln element för element och ger exempel hämtade från det klimatpolitiska området. Vi identifierar också områden som är intressanta för fortsatt forskning. Till exempel behövs metoder för jämförelse av olika styrmedels kostnadseffektivitet, djupare analyser av olika inspektionsmetoders effektivitet på kort och lång sikt samt fler studier av kausaliteten mellan ett styrmedel och dess effekter. 


\begin{abstract}
We propose a framework for studies of efficiency in environmental policies in the form of an iterative "policy cycle". The policy cycle's six major elements are goal-setting, choice of policy instruments (information/communication, voluntary agreements, economic instruments and regulation), enforcement, changes in behaviour of public and private agents, effects of policy measures and, finally, evaluation. Through iterations of the policy cycle (or parts of it), efficiency in environmental policies can be improved. The policy cycle is applied to climate policies, both mitigation and adaptation and we identify important areas for future research.

Keywords: Policy cycle, environmental efficiency, mitigation, adaptation, goal-setting, voluntary agreements, regulation, behavioural change, evaluation.
\end{abstract}




\section{Contents}

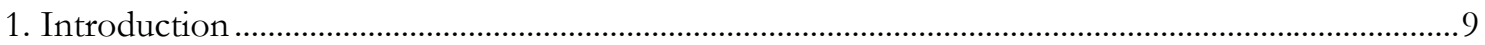

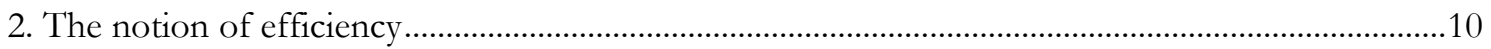

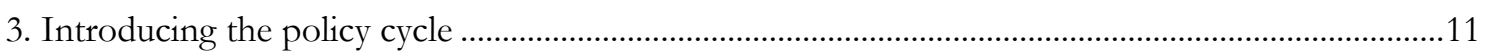

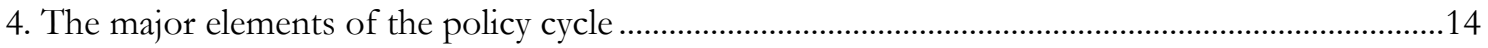

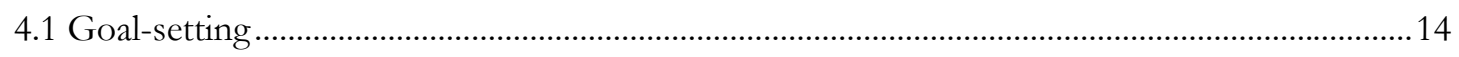

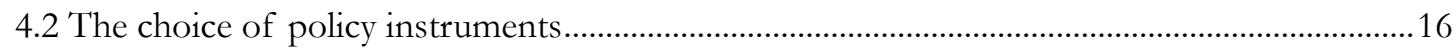

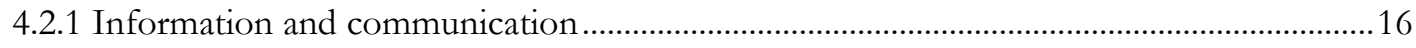

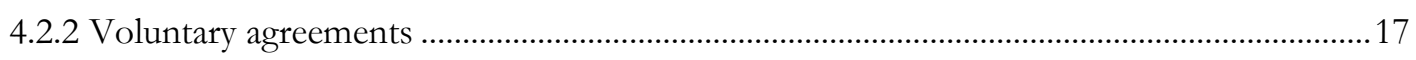

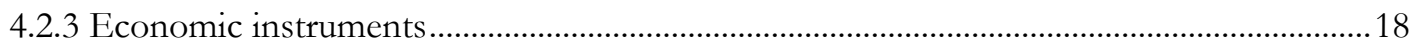

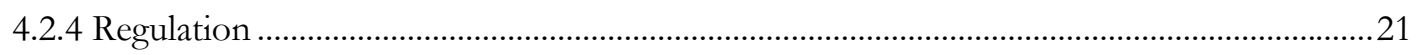

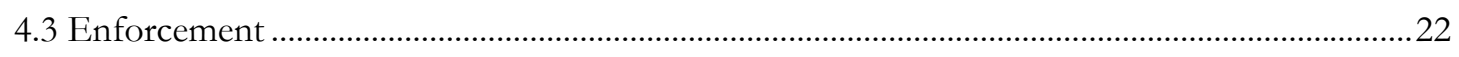

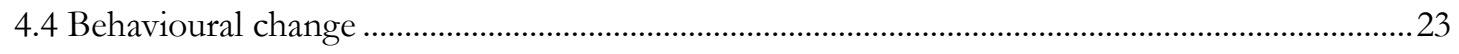

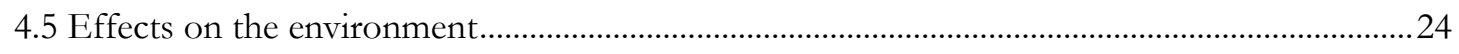

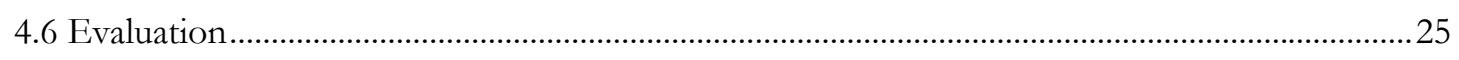

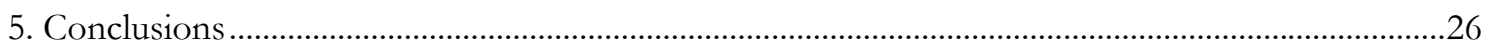





\section{Introduction}

The implementation of policies is a complex and difficult task. This applies to environmental policies in general and possibly to climate policies in particular. Although most of the actual implementation has to be performed by the firms, organizations, and individuals whose activities give rise to the problems, public agencies have an essential role in developing strategies and methods for implementation, enforcement, control, and evaluation. In addition, since environmental problems, including climate change, are often transboundary and policy implementation mostly is national, international coordination problems arise.

Ideally, one would wish the choice of policy instruments to be based on conclusive scientific results on the impacts of various types of instruments, so that a suitable combination of, for example, information and economic instruments can be selected. In practice, this rarely happens. The effects of policy instruments are often difficult to ascertain, and in most cases too little scientific or otherwise systematized information is available to guide decisions. Therefore, decisions in this area often have to be based on unsystematized experience and intuitive judgment - in addition to political negotiations.

Public agencies therefore need improved knowledge about the effects of policy instruments. Such knowledge can be obtained through evaluation of the effects of implemented measures. By systematically evaluating the (positive and negative) effects of policies and policy implementations, experiences are gained that can be used for predicting the effects of proposed actions. Evaluation work is currently being performed in many government agencies, but it often takes place under conditions that are far from optimal. Evaluators seldom have the opportunity to influence policy design $e x$ ante in order to make the policies evaluable expost. More often than not, new policies are introduced in a way that does not allow for comparisons with previous or alternative methods. Experiences and results from other countries' efforts to solve the same problems are not always sufficiently made use of. Generally speaking, evaluation work is seldom given enough priority to ensure that the impact of agency measures can be determined. Such efforts do not have the high status that they deserve, and most agencies still lack an "evaluation culture" that integrates impact evaluation with planning and implementation.

However, evaluation of environmental policies is not a task for the public agencies alone. To be successful, public agencies need support from academic research. Unfortunately, insufficient scientific guidance is available in this area. Although the theoretical effects of some policy instruments, in particular certain economic instruments, have been carefully studied, too little empirical information is available about the effects of some of the most common types of government action in the environmental area. This applies in particular to activities such as inspection and information.

The evaluation of environmental policies is a truly interdisciplinary field. It requires competence and methodologies from various disciplines in the social and behavioural sciences, including economics, decision theory, risk research, sociology, political science, public administration, policy analysis, social anthropology, and social psychology. Research in a variety of natural sciences, including ecology, climatology, environmental chemistry, toxicology, ecotoxicology, and epidemiology are needed to determine the effects of environmental policy instruments. Furthermore, this research 
requires inputs from practitioners, i.e., from persons who have experience from government agencies, industry, NGOs, and other organizations involved in the implementation of environmental policies.

The purpose of the present contribution is to describe a simple framework for studies on the efficiency of environmental policies, in particular in relation to climate change, and to identify major research problems that have a high degree of practical relevance in this area. In section 2 we clarify the concept of efficiency. In section 3 we present the framework in the form of a policy cycle that can be used for studying the elements of policy implementation. In section 4 each of the elements of the policy cycle is discussed in more detail, and in section 5 we summarize our conclusions with respect to research needs in the area.

\section{The notion of efficiency}

The notion of efficiency is often used ambiguously though its core meaning is simple enough. Efficiency means satisfaction of goals (Le Grand, 1990 and 1991). Therefore, efficiency must always be defined in relation to an (explicit or implicit) set of goals. In some cases, we refer to only a single goal, and efficiency (in this case more commonly called effectiveness) means that the goal in question is satisfied to as high a degree as possible. In most cases however, efficiency refers to two or several goals. Then a measure is efficient (with respect to the given goals) if, and only if, none of the goals could have been achieved to a higher degree without some of the others being achieved to a lower degree.

Discussions of efficiency are often confused by a lack of precision with respect to the identity of the goal dimensions. In environmental contexts, the two most important notions of efficiency are effectiveness and cost-efficiency. An environmental policy instrument is effective to the extent that it solves the environmental problem that it is intended to achieve. Effectiveness has nothing to do with costs. An effective policy instrument may very well be indefensible because it requires too much of resources that could have been used better. A policy instrument is cost-efficient to the extent that it is efficient with respect to two goals, of which one is cost containment. In environmental policies the other goal is environmental improvement, and then the instrument is cost-efficient if, and only if, no alternative exists that achieves better environmental effect at the same or lower cost, or less expenditure for the same or better environmental effect. A cost-efficient alternative may very well be indefensible, either because it produces too little environmental effect (albeit at low cost) or because it is too expensive.

In the context of climate mitigation, cost efficiency means that as much reduction of the increased greenhouse effect as possible is achieved at a given cost or that a given reduction is achieved at the lowest cost. The major problem in determining the costefficiency of climate mitigation consists in determining the impact an isolated action has on the emissions of greenhouse gases and, eventually, on the climate. In the context of climate adaptation, cost-efficiency means reducing the negative impacts of climate change (or increasing the beneficial impacts) as much as possible to a given cost (or, analogously, to achieve a benchmark impact at the smallest cost). A major difficulty here is how to assign relative weights to different positive effects of adaptation; these may be as different in nature as reduced frequency of flooding and prevention of heat-related deaths (see Hansson, 2007a). 
Clearly, both effectiveness and cost-efficiency are of interest as policy-guides. It is important to note that effectiveness, i.e., the degree to which environmental goals are satisfied, is an essential component of cost-efficiency and, indeed, of any meaningful measure of efficiency in environmental policy implementation. Therefore, the first and most basic element in the analysis must be to determine, as accurately as possible, the degree to which the desired effects are in fact achieved. Reliable information on that is still rare, largely due to methodological difficulties. In many cases, intervention studies with control groups are the only practicable means to isolate the effects of a policy intervention from the confounding effects of other causes. Only few such intervention studies have been performed for environmental policies. Even in other policy areas where data for policy evaluation is abundant, e.g., labour market policies, it is difficult to ascertain the causality between a policy and its effects.

\section{Introducing the policy cycle}

It is common in evaluation studies to treat interventions as simple one-link causal relationships of the type shown in Figure 1. Since an intervention is intended to achieve a certain effect (e.g., reductions of carbon dioxide) it is logical for evaluation studies to focus on finding out whether that effect has in fact been achieved.

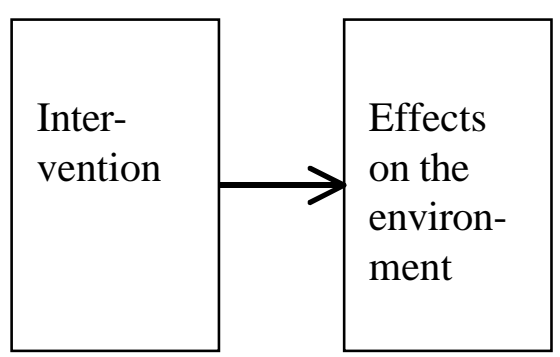

Figure 1. A one-step model of environmental interventions.

This simplified model is however often unsuitable for evaluating interventions undertaken by government agencies. In most cases, agencies do not themselves perform the physical actions that are intended to lead to a better environment. Instead, the measures taken aim at influencing the behaviour of other, mostly private agents (private persons, households, and companies) who will, in turn, more directly influence the environment, see Figure 2.

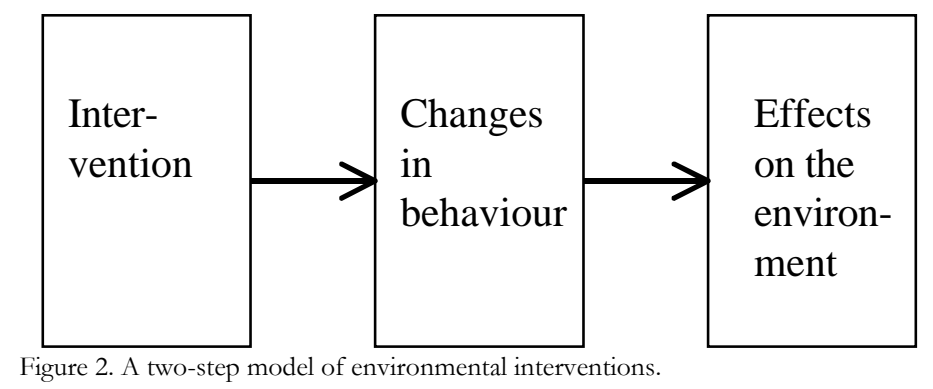

In most cases it is easier to establish each of these two links in the causal chain separately than to establish their combined effect. For an example of this, consider a campaign consisting of information to companies about the detrimental effects on the climate of airplane travel. The purpose of this campaign is to make companies de- 
crease their contribution to the greenhouse effect by reducing airplane travel. A direct investigation of the effects of this information campaign on the climate would be impossible since any such effects are sure to be hidden behind many other, much larger effects on the climate. We take it for granted in a case like this that what we should evaluate is not the ultimately desired effect, namely a positive effect on the climate, but an intermediate effect that is practically accessible to evaluation. The reason for this is, as already indicated, that there is a large number of confounding factors that also influence the climate. The confounders can be divided into two groups. The first group consists of those that disturb the first link in the causal chain, from information to decreased airplane travel. This group may include for instance changes in airplane fares, effects of debates in mass media about the impacts of air traffic on the climate, other negative publicity about air travel, and technological improvements in videoconference technology. The second group consists of those confounders that act on the causal link from decreased air travel to reduction in the (global) greenhouse effect. This group includes variations in a large number of social and natural factors that influence the climate, for instance, volcanic eruptions and compensating behaviours such as increased car driving. In a study that focuses directly on the effects of the information campaign on the climate, the combined effects of all the confounders in the two groups would make the effects of the campaign on the desired environmental end-state impossible to identify. If each of the two links of the causal chain is studied separately, chances are better to control for confounders so that the hypothesized causal links - if existent - can be discovered. In this particular case, the first link of the causal chain, i.e., between the information campaign and reduced airplane travel, can be studied empirically, whereas the second link, i.e., between reduced airplane travel and reduced greenhouse effect, has to be judged according to theoretical climate models. In general, it is often preferable to study the two causal links indicated in Figure 2 separately in order to increase the sensitivity of the evaluation (Hansson, 2007b).

The model shown in Figure 2 is still incomplete in one important respect: It does not include the process of goal-setting. This is an important component in environmental policy-making that has to be taken into account in evaluation studies. Insufficiently operational goals can be an important source of inefficiency, and the lack of precise goals can also make the implementation process impossible to evaluate. This leads us to the model shown in Figure 3. We call this the policy cycle for environmental interventions, but the use of a cyclic model to describe decision processes is of course not new (see e.g., Mintzberg et al., 1976).

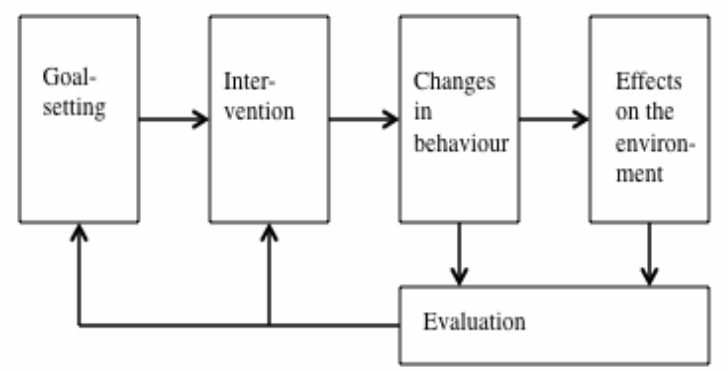

Figure 3. The policy cycle in its general form. 
For our present purposes, it is useful to treat the different forms of interventions separately, as in Figure 4.

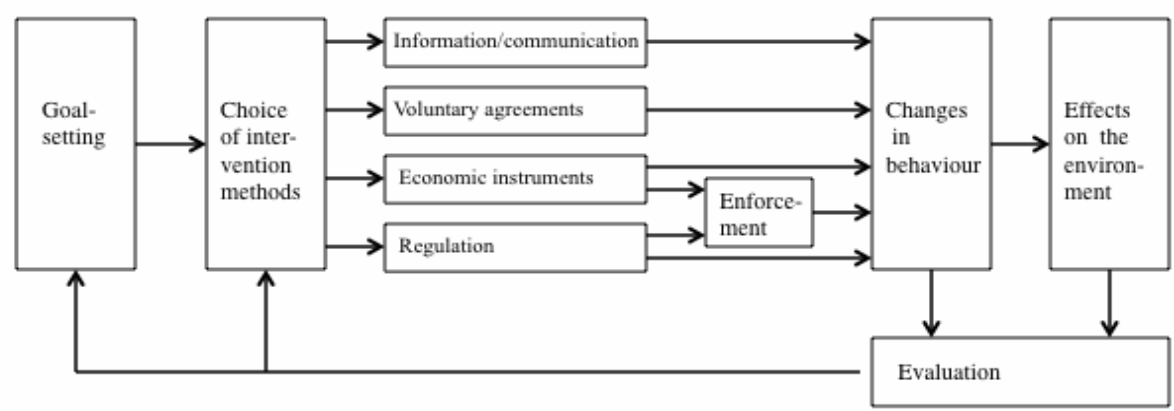

Figure 4. The policy cycle, extended version with explicit treatment of several major types of policy instruments.

As shown here, the policy process begins with (1) goal-setting, which is followed by (2) a choice of one or several policy instruments that will usually fall into four major categories (i) information/communication, (ii) voluntary agreements), (iii) economic instruments and other instruments that influence behaviour by adjusting the preconditions of choice, and (iv) regulatory instruments. The latter two types of interventions are accompanied by (3) enforcement measures to ensure that, for example, taxes are paid, emission limits not exceeded, etc. The application of policy instruments is intended to lead to (4) changes in the behaviour of actors who directly influence the environment. These changes, in turn, are intended to have (5) positive effects on the environment. Then (6) evaluation studies are applied to behavioural and environmental changes in order to capture both links of the causal chain described above. The outcome of evaluation studies is applied to improve the various elements in the model, in particular goal-setting and the choice of policy instruments for goal achievement. Through iterations of the policy cycle, policy objectives can be achieved more efficiently.

The policy cycle, as described here, is idealized in both senses of the word. To idealize can mean to simplify for the sake of clarity. It can also mean to describe something as better than it really is (Hansson 2003). The policy cycle as presented here is clearly an idealization in the first sense. We abstract from many complications in actual policy processes, and there are some types of policy instruments that we have not mentioned, such as support to research that can provide new technical solutions and environmental "nudges", i.e., changes in choice architecture that alter people's behaviour so that environmental goals are more easily achieved (Thaler and Sunstein, 2008). The policy cycle is also an idealization in the second sense, not least since we presume a systematic and rational use of goal-setting and evaluations that is not always present in practical policy-making. Even when evaluations take place, they are often not connected to the other parts of the process in the manner shown in Figures 3-4. We believe, however, that the components included in the proposed policy cycle are essential in an efficient policy process. Therefore, they should all be included in research on the efficiency of such processes.

The framework we propose is more detailed than the European Environment Agency's DPSIR (Drivers-Pressures-States-Impacts-Responses) framework (Smeets and 
Weterings, 1999; Gabrielsen and Bosch, 2003), which is intended to be a "causal framework for describing the interactions between society and the environment" (EEA Glossary, 2011). Although useful for structuring the analysis of environmental problems at a general level as well as for communication with policy-makers, the DPSIR model is overly simplistic and disguises some major difficulties in each of its separate elements (Maxim et al., 2009).

In relation to the DPSIR, our framework concerns the effectiveness of the policy choices and is, as such, an elaboration of the links between the response (R) and the other elements of the DPSIR framework. Assessment of policy effectiveness can provide vital information for improving policy. Our framework, i.e., the policy cycle, illustrates an iterative process of fine-tuning policy responses to environmental targets.

\section{The major elements of the policy cycle}

In the following subsections, each of the six elements of the policy cycle, as presented in Figure 4, will be discussed, and research needs will be identified.

\subsection{Goal-setting}

Environmental policies, including climate policies, are to an increasing extent operationalized through goals and targets set at international, national and local governmental levels. This holds in particular for climate mitigation policies, for which several international agreements have been adopted (e.g., the United Nations Framework Convention on Climate Change (UNFCCC), the Kyoto Protocol and the Copenhagen Accord). The ultimate aim of international efforts towards mitigation is to stabilize " $[\mathrm{g}]$ reenhouse gas concentrations in the atmosphere at a level that would prevent dangerous anthropogenic interference with the climate system" (UNFCCC, Article 2). However, the precise meaning of this goal remains unclear (Oppenheimer 2005; Oppenheimer and Petsonk 2005), and there are different modes of operationalizing it (Philibert and Pershing 2001). The UNFCCC goal is most commonly operationalized through emission targets (both fixed and indexed), atmospheric concentration targets, and temperature targets. Although these three types of mitigation targets are clearly related to one another (concentration targets can, albeit with considerable uncertainty, be derived from temperature targets, and emission targets can, with similar difficulties, be derived from concentration targets), national and international governments should nevertheless consider carefully how to formulate their mitigation targets. Mitigation targets serve different functions; they help to structure action, commitments and institutions; they help to mobilize society and stimulate action; and they provide a standard against which implemented measures can be assessed and evaluated (Pershing and Tudela, 2003; Gupta et al., 2007). Different types of targets may fulfill these functions to varying degrees. For example, temperature targets may be easier for the general public to understand and commit to than emission or concentration targets; but they can be difficult to further operationalize due to the stochastic nature of temperature outcomes (Stern, 2008).

Since climate policy goals are intended to guide decision-making, it is essential to study what makes them effective, or rational (Edvardsson and Hansson, 2005). Despite the central role of goal-setting in climate policies, little has been written on the goal- 
setting process or on how climate goals should be constructed to have maximal effect. For goals and goal-setting in other areas an abundant literature is available on the desirable properties of goals and the prerequisites for efficient management by objectives. ${ }^{1}$ In contrast, for environmental goals in general, and climate policy goals in particular, the discussion is much more limited. ${ }^{2}$ Several factors contribute to make the adequacy and efficiency of climate policy goals difficult to determine, in particular the complexity of environmental-social processes, the uncertainties involved, the spatial and temporal variability of the targeted effects, and the multidimensionality of the value issues that have to be dealt with.

In actual political practice, climate policy goals are not the only goals governments are responsible for achieving. To the contrary, efforts are directed towards many different goal areas: the labour market, regional development, economic stability and development, social justice, transportation, etc. Since political decision makers want to achieve a multitude of objectives, it is interesting to study how systems of goals should be organized to be as transparent as possible and to facilitate decision makers' efforts to come as close as possible to what they want to achieve. This requires that potential conflicts and synergies between different goals are identified and analyzed.

Goal conflicts (and synergies) in mitigation have received quite extensive attention, both in international negotiations and in the scientific literature (e.g., Barker et al., 2007; Peterson and Rose, 2006). It has, for example, been pointed out that spending money on emission reductions could mean that less money is available for the achievement of important development goals, such as the reduction of poverty, malnutrition and infectious disease (Schelling 1995; Tol 2005b). Goal conflicts (and synergies) in adaptation have been less studied. ${ }^{3}$ This is unfortunate since goal conflicts are common in climate adaptation. Adaptive actions can make it more difficult to achieve goals concerning the preservation of natural, cultural/aesthetic or recreational values, such as when hard coastal defences that are erected to protect from flooding pose a threat to biological diversity, change the coastal landscape and render beach leisure less attractive. Adaptation measures can also conflict with the goal of mitigation, such as when the production of artificial snow to compensate for snow deficits increases energy use and, hence, $\mathrm{CO}_{2}$ emissions. Sometimes, taking action to reduce vulnerability to climate change at one geographical location or point in time can increase the vulnerability at some other location or point in time, such as when flood defences that are erected on one side of a river increase the risk of flooding on the opposite side of the river (Edvardsson Björnberg and Hansson, in press).

To better understand the effects of goal-setting practices on the efficiency of climate interventions, further studies are needed of climate policy goals and targets and their use. In addition to rationality criteria for single goals, such an analysis will need methodology for analyzing relationships between goals. The development of tools for precise analysis of these aspects is an important prerequisite for a better understanding of the effectiveness of climate policy instruments.

\footnotetext{
${ }^{1}$ See, for example, Odiorne (1969), Carroll and Tosi (1973), Quinn (1977), Locke and Latham (1990), van Herten and Gunning-Schepers (2000), Hall and Kerr (2001), Johnston et al. (2001) and Latham (2003).

${ }^{2}$ Important exceptions include Corfee-Morlot and Höhne (2003) (mitigation) and Horrocks et al. (2005) (adaptation). See also Stead (1997), Slocombe (1998) and de Jong (1998) for discussions of the desirable properties of environmental goals.

3 However, there are exceptions. Conflicts and synergies between the goals of adaptation and mitigation have, for example, been studied by Tol (2005a), Mc Evoy et al. (2006), Klein et al. (2007) and Hamin and Gurran (2009). Edvardsson Björnberg and Svenfelt (2009) provide a systematic inventory of potential conflicts between the goal of adaptation and other environmental policy goals.
} 


\subsection{The choice of policy instruments}

Whereas climate policy goals are set by political decision-makers and implemented by public administrators, choices of policy instruments take place on different decisionmaking levels. ${ }^{4}$ Economic interventions, such as emissions taxes, are decided on a central political level in a fairly detailed manner. In contrast, decisions about enforcement and information/communication are to a large degree delegated to administrators, and the same applies to many types of regulation, in particular industry-specific regulations. Similarly, it is often delegated to agencies to conduct negotiations with private actors, such as firms and industry associations, in order to obtain voluntary commitments concerning, for example, emission reductions.

The choice of intervention methods is clearly complicated by this division of decisionmaking between different levels. An additional complicating factor is the lack of comparable empirical data on the efficiency of economic and non-economic (e. g., legislative and informational) instruments. In order to improve the decision-making situation, so that optimal policy instruments can be chosen, research is needed that compares different policy instruments and combinations of such methods. In addition, the nature and the effects of the division of decision-making on environmental intervention between different political and administrative levels is an important research area.

\subsubsection{NFORMATI ON AND COMMUNICATION}

Communication about environmental problems and ways and means to solve them is one of the major environmental policy instruments. As was noted by Magat and Viscusi (1990), for information dissemination to be useful, there must be an information gap for the information to alleviate. They also suggested that informational efforts are most desirable in situations with an element of individual choice and particularly when individual behaviour cannot be monitored and enforced. To this it should be added that information and communication strategies are relevant not only in relation to individual persons and households but also to companies and other organizations. That is, informational policies are about changing what people and organizations think and do.

Concerning mitigation, information and communication are considered important means of raising awareness of climate issues and creating appropriate social environments for emission reduction policies (IPCC TAR, 2001). Information is also believed to influence individuals' preferences concerning mitigation and assist the public in making the right kinds of choices concerning greenhouse gas reductions. Information/communication measures can, for instance, be used to influence individuals' choices of transport and heating technologies.

Information and communication are also of central importance in adaptation, not least since many of the measures that are advisable to cope with extreme weather events have to be taken individually. This includes for instance the precautions to be taken in the event of heat waves or flooding in order to avoid water-, food- and vector-borne infections.

4 In practice, the actual division of tasks is complex, since authorities often have a large influence on goal-setting. The combination of complex and visionary objectives with an inevitable lack of resources makes it necessary for administrators to set priorities. In this way, important parts of the political process are often delegated to administrators without a political mandate (Lipsky, 1980). 
In the last two decades, the study of risk communication has been one of the fastest growing subdisciplines of risk research. One of the most consistent findings is that risk information is very difficult to communicate. It was proposed by Horst $e t$ al. (1986) that this may largely be due to the complexity of human information processing. However, results have also been obtained showing that the choice of communication methods can make a significant difference. In a study by Wogalter et al. (1987), compliance decreased from 90 to 50 percent when a warning was moved from the beginning to the end of a set of instructions. More general results confirm that subtle changes in presentation may have a major impact on perceptions and behaviours (Kahneman and Tversky, 1979, Slovic et al., 1979 and 1980, Lehto and Miller, 1986, Drottz-Sjöberg, 1993, Sjöberg and Drottz-Sjöberg, 1998).

Most of the literature on information measures has been devoted to information directed at individuals. For the success of climate policies, the effects of information directed at firms and their managers are at least equally important. Furthermore, even with respect to information to the public, there is not much systematic knowledge of the conditions of success. Comparative studies of different communication strategies are rare, and no data seem to be available that can be used to compare the effects of communication to those of regulation or economic instruments. According to Coffman (2002) the lack of knowledge about the effects of information campaigns results from evaluators missing the necessary tools for evaluation. For example, impact evaluations, which can, if adequately performed, determine whether a campaign has the intended effects on measurable outcomes, are rarely performed because they are resource intensive and require some form of experimental research design with treatment and control groups.

\subsubsection{VOLUNTARY AGREEMENTS}

The term "voluntary agreement" is commonly used to denote an agreement in which one or more private actors make a commitment to improve their own environmental performance beyond legal requirements. The agreement can relate to general issues, such as energy efficiency or reporting of emissions, or it can relate to a specific environmental objective such as an emission target. Three main types of voluntary approaches exist: public voluntary programmes (which involve commitments formulated by the public authority and in which firms are invited to participate), negotiated agreements (which involve commitments developed through bargaining between the public authority and industry), and unilateral commitments (which are basically initiated by the industry without any involvement of a public authority) (OECD, 1998; Börkey and Lévêque, 2000).

Voluntary agreements are increasingly popular as an instrument to cope with environmental problems, and in some cases (for example in the U.S.) they are practically the only instruments that regulate emissions reductions (OECD, 2003). Voluntary agreements have many advantages: they provide an opportunity to cope with environmental issues in a low cost and flexible way and are, therefore, relatively acceptable to many industries; they usually require less preparation to put in place than regulatory measures (e.g., taxes) and, therefore, they allow for faster and smoother achievement of environmental objectives. They also usually require less intensive monitoring and, therefore, come with lower administrative costs (Dijkstra, 1998; Croci, 2003; Bailey, 2008). But there are also critical voices. Voluntary agreements have been criticized for 
being less effective than economic instruments in promoting environmental and economic goals and for achieving little more than "business as usual" strategies (Bailey, 2008). There are also problems associated with asymmetric information (where the industry has the informational advantage), non-compliance and free riding (Glachant, 1999; Croci, 2005).

Although many evaluations have been performed on the effectiveness of voluntary agreements (e.g., Baranzini and Thalmann, 2004; Ekins and Etheridge, 2006; Davies and Makuch 2009), relatively little is known about the effectiveness of voluntary agreements compared to other policy measures. In order to determine the effectiveness of a voluntary agreement three questions need to be addressed (OECD, 2003):

(1) Have the targets in the agreement been set at an appropriate level?

(2) Have the targets been met?

(3) To what extent has the agreement contributed to achievement of the targets?

Answering the first question presupposes that the evaluator has access to information about the regulated firms' marginal social benefits and costs at the time when the agreements were made. Such knowledge is often difficult or impossible to obtain. The second question can be difficult to answer due to measurement problems, for instance if there is heterogenous reporting on progress towards achievement of the targets, i.e., if the numbers that the firms provide differ from official data. The third question raises a counterfactual issue; it is difficult to ascertain what measures the companies in question would have taken in the absence of an agreement (or if other instruments, such as economic instruments or regulations, had been used instead), especially since information asymmetries can generate self-selection into voluntary agreements. Knowledge is still lacking about which factors are most critical to the success or failure of different types of voluntary agreements (Bailey, 2008). In a review of a number of case studies on voluntary agreements performed by the OECD (2003), the conclusion was that factors beside the voluntary agreement explain most of the environmental improvement in those cases.

Relatively few empirical studies have been conducted on the impacts of voluntary emissions reductions compared to business-as-usual emissions abatements (Thalmann and Baranzini, 2004). Since voluntary agreements have an increasing role in environmental policies (e.g. the Copenhagen Accord), more empirical analysis of different types of voluntary agreements is needed to ascertain their effectiveness (i.e., their ability to achieve the objectives they target) and cost-efficiency relative to other types of instruments. It is also interesting to investigate how the efficiency of voluntary agreements can be improved by combining them with other types of instruments.

\subsubsection{ECONOMIC INSTRUMENTS}

Economic incentive policy instruments (in short: economic instruments) are incentives-based instruments that work through the price system, e.g., emissions taxes, deposit-refund schemes, tradable emission permits and subsidies. The main advantage of these instruments is that, at least in theory, they minimize the aggregate cost of achieving a given level of environmental protection. The theoretic literature on economic instruments and their efficiency is abundant. ${ }^{5}$ In spite of the theoretical cost- 
minimizing character of economic instruments, the choice of instrument also depends on, e.g., interest group pressures, political negotiations, administrative considerations, enforcement costs, distributional issues, and the presence (or absence) of incentives for the development and diffusion of better and cheaper abatement technologies. Thus, the choice of policy instruments depends both on the environmental problem addressed and on the social, political, and economic context in which the instrument is to be implemented.

In theory, much can be learned about the properties of different economic instruments from analyzing two functions; the emitters' aggregated marginal abatement cost function and the victims' aggregated marginal damage function. The marginal abatement cost function summarizes the emitters' marginal costs (MC) for reducing the emissions. It depends on both the production and abatement technologies, and can be expressed as a function of the level of emissions. In theoretical analyses this function is often assumed to decrease with the amount of emissions, so that the marginal cost for reducing an additional unit is higher at low emission levels, see Figure 5. The marginal damage function (MB) shows the disutility (in monetary terms) of the damages caused by the emissions and reflects the marginal benefits from reduced emissions. In theoretical analyses this function is often assumed to increase with the amount of emissions.

To illustrate some important issues in the choice of policy instruments we can contrast an economic instrument, such as an emissions tax, with a non-economic instrument such as a quantity regulation. Under the assumption of perfect knowledge about both the aggregate marginal abatement cost function and the aggregate marginal damage function, an emissions tax and a quantity regulation can be designed to be equal in terms of effectiveness and cost-efficiency. If the decision maker has complete knowledge, (s)he can either specify the allowable level of emissions for each source of emissions $\left(\mathrm{Q}^{*}\right)$ or tax every unit emitted with a tax equal to the emission's (equilibrium) marginal damage $\left(\mathrm{P}^{*}\right)$. Only in terms of the revenues and the rights to emit do the instruments matter (Bovenberg, 1999). Furthermore, a tax generates a public revenue that can be used to compensate the victims (or the emitters).

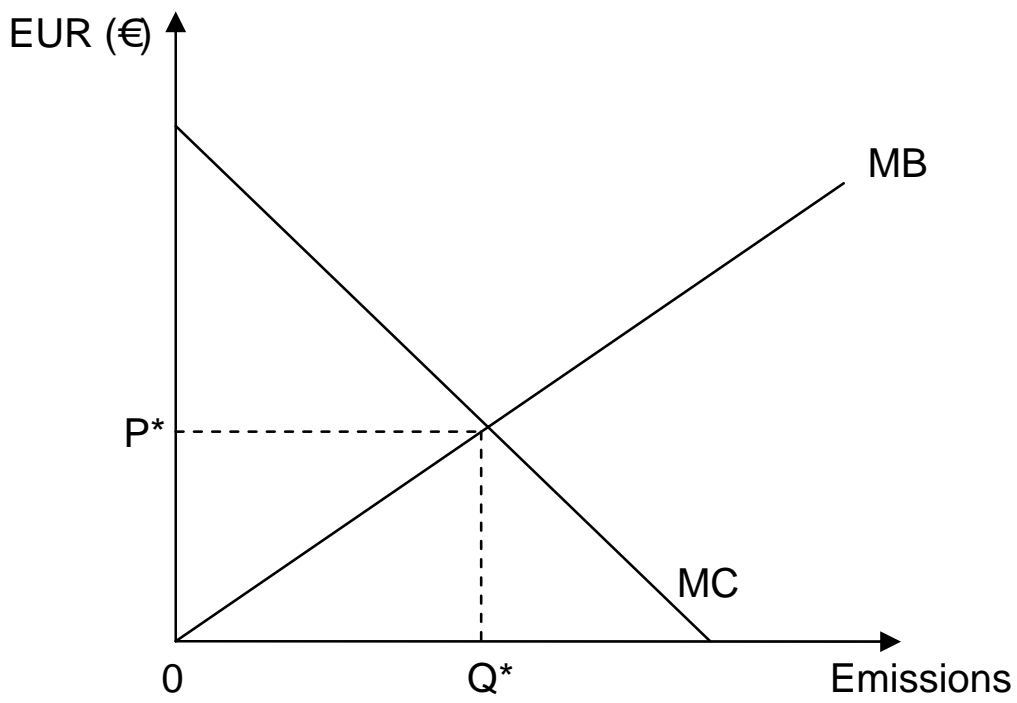

Figure 5. The relationship between the marginal damage cost function (MB), the marginal control cost function (MC) and the emission level. 
In real life, there is rarely perfect knowledge about the marginal damage and abatement cost functions. Under imperfect knowledge, the welfare loss associated with missing the environmental target has been shown to vary with the instrument chosen (Weitzman, 1974; Baumol and Oates, 1988). Based on these findings, a simple rule of thumb is to choose a quantity regulation when the welfare loss from not attaining the environmental target is high (e.g., dealing with extremely hazardous substances) and an emissions tax when the welfare loss from non-attainment is smaller. With imperfect knowledge about the marginal damage and abatement cost functions, a quantified environmental target is more easily achieved with a regulation than with an emissions tax. The associated cost may, however, be very high. On the other hand, emissions are reduced cost-efficiently with a tax, although the environmental target may not be achieved.

Even if the polluters' marginal abatement cost functions are not known to the decision makers, they are, presumably, at least to some extent known to the polluters. On the other hand, troublingly little is known about the marginal damage functions - both to the decision makers and the victims.

In sum, economic instruments are often, but not always, cost-efficient means to achieve a given level of environmental protection. Although much is known about the use of these instruments in theory, important empirical research remains to be performed in order to determine the conditions under which (different types of) economic instruments are efficient means to achieve specific environmental objectives, especially when a new economic instrument is introduced in a world with pre-existing economic instruments (Bovenberg and Goulder, 1996; Goulder, 1998; Goulder et al., 1999; Goodstein, 2003; Jaeger, 2004).

Thus, economic instruments such as taxes can successfully be used to mitigate emissions of $\mathrm{CO}_{2}$ and other greenhouse gases. The potential of economic instruments to encourage adaptation to climate change has, however, received less attention. According to the OECD (2008), the design of "smart" policies can however promote adaptation. Two examples of such smart policies are insurances and environmental markets.

In a simple and ideal situation, a market-priced "climate insurance" would send the correct signal to the market about the costs of not adapting to climate risks. Individuals would respond to the signal either e.g. by climate-proofing their businesses and homes or, if the insurance premium is considered to be too high, by relocating to a less risky area. In this way, a climate insurance could encourage adaptation.

An environmental market is a market where an environmental resource is priced in order to attain allocative efficiency. Water markets have, for example, successfully been implemented in the Murray Darling Basin in Australia (see www.mdbc.gov.au). On the water market farmers can either increase their allocations to sustain agricultural output or reduce their allocations to get financial compensation. A water market can also provide a forum for accommodating disputes and may, therefore, also be effective in the adaptation to risks of water shortage induced by climate change. 


\subsubsection{REGULATION}

Economic instruments involve an explicit compromise between environmental and non-environmental (economic) goals. Regulatory instruments, such as emission limits and specifications of prescribed or prohibited technology, do not explicitly refer to costs. Sometimes, exposure limits for toxic substances are described as uncompromisingly concerned only with the environment or human health. However, due to the uncertainty inherent in all risk assessments, above-zero levels of emissions or exposures cannot be known for sure to have no negative impact. Therefore, the vast majority of regulations involve an economic compromise, although it is usually less explicitly expressed than for economic instruments (Hansson, 1998).

Regulations are a common means of reducing the emissions of $\mathrm{CO}_{2}$ and other greenhouse gases. To increase energy efficiency the EU member states have, for example, endorsed a regulation to phase out incandescent light bulbs between 2009 and 2012 (European Commission, 2009). A potential ban on the use of nitrous oxide as an analgesic has also received considerable public attention in Sweden.

Regulations have a central role in adaptation where they can be used to decrease vulnerability to climate change. Examples of regulatory adaptation measures that have been considered are modifications of building codes, stricter legislation for water use and stricter water-quality guidelines, and more restrictive legislation concerning land use, especially in areas prone to flooding and erosion (Health Canada, 2008; Swedish Commission on Climate and Vulnerability, 2007).

Depending on how a regulation is constructed, the inherent compromise between environmental and economic objectives can take place on different levels of generality. On the least general level, regulations apply to specific firms or plants. Emission limits for toxic substances are an example of this. In most jurisdictions they are determined for each plant, based in practice on a compromise between environmental requirements and economic conditions in the particular case. On a somewhat more general level, regulations can be laid down for a specific type of process, procedure, or exposure. As an example of this, the precautions required in the handling of explosives are in most cases general and apply to all firms in which such substances are used.

Regulating on a low level of generality, such as on a single firm, has the advantage that economic optimization can be more fine-tuned. On the other hand, higher levels of generality have the advantage that uniform principles can be established and that firms are treated more fairly in the sense that the same rule applies to all of them. Another way to express this is that if the regulator has access to reasonably accurate information about the marginal costs involved in the regulated companies, then less general regulations can be more similar in their effects to economic instruments than more general regulations.

The choice of a level of generality appears to depend largely on traditions that differ between different problem areas. Health and safety regulation is, in general, uniform for all firms with a certain process or exposure, whereas it is more common for environmental regulation to be firm-specific (Hansson, 1998). Regulations on greenhouse gas emissions tend, however, to operate on high levels of generality, such as processes or branches of industry. It remains to investigate why different aggregation levels have been chosen for different regulations and to clarify the effects of these choices. 


\subsection{Enforcement}

As we have already indicated, enforcement is needed as a complement to regulations and economic instruments. It is also needed to ensure adherence to binding voluntary agreements. However, the forms of enforcement tend to differ between the different types of instruments.

Inspection by governmental inspectors and self-monitoring are the main forms of enforcement of regulations. They are also adequate ways to follow up the effects of binding voluntary agreements. So far, inspection has had a less conspicuous role in climate policies than in other parts of environmental policies, but there are reasons to believe that this will change. Government inspections together with self-monitoring and third-party inspection is expected to play an increasingly important role in the future enforcement of, for example, more rigorous building and water quality regulations.

Most of the research on the efficiency of inspections has been performed on health and safety inspections in the USA. It can be concluded from these studies that inspections by governmental inspectors tend to increase compliance with health and safety regulations and reduce injury rates (Scholz and Gray, 1990; Gray and Scholz, 1993; Weil, 1996). Most of this effect seems to derive from the initial inspection, whereas subsequent inspections tend to have little effect on compliance (Gray and Jones, $1991 a$ and 1991b). There are also indications that the magnitude of the penalty is insignificant, i.e., small penalties decrease injuries as much as large ones (Gray and Scholz, 1991). (For an overview, see Lindblom and Hansson, 2004.) We are only aware of one study of inspection that randomized companies between an inspected group and a control group. According to that study, inspections by the Swedish labour inspectorate had large positive effects on the noise abatement measures on workplaces (Björkdahl et al., 2008).

Very few studies have been performed on the effectiveness or efficiency of environmental inspections. The available studies tend to confirm the results obtained in studies of health and safety inspections. A study of the enforcement of American air pollution regulation on steel plants showed that inspections led to improved compliance (Gray and Deily, 1996). Similarly, EPA inspections of pulp and paper plants with respect to water pollution turned out to have a strong effect on compliance with the permit levels (Magat and Viscusi, 1990). A study of inspections in the Québecois pulp and paper industry confirmed this result, and also showed that the mere threat of an inspection led to improved compliance (Laplante and Rilstone, 1996). This result was confirmed in a study of inspections at petroleum storage sites in Manitoba, Canada (Eckert, 2004).

As mentioned above, economic instruments also require enforcement measures to ensure compliance. Research on this form of enforcement is even scantier. This may be due to the relative novelty of these instruments, and perhaps also to a lack of understanding about their need of enforcement.

Judging by the available evidence, enforcement methods for economic instruments are in general different from those used for regulations. While environmental regulations are primarily enforced through inspections, economic instruments are often enforced through consistency checks of register data. For example, the enforcement of the EU 
ETS is based on self-reports to national registries and to a central EU registry (Directive 2003/87/EC) and carried out by comparisons of registry entries. Thus, the actual emissions of $\mathrm{CO}_{2}$ from, for example, a district heating plant can be estimated from the carbon-content of the fuels used, and their consistency with permit holdings can be checked. According to Tinggaard Svendsen and Vesterdal (2003), the likelihood of detecting cheating is relatively high in such consistency checks.

In addition to a high detection probability, successful enforcement requires a carefully constructed set of sanctions. Financial penalties, forfeiture of future permits, forfeiture of participation in the trading program and criminal penalties are examples of such sanctions (Tietenberg, 2002). In the EU ETS, there is a penalty of $€ 100$ for every tonne $\mathrm{CO}_{2}$ emitted without permits. During the first trading period, 2005-2007, the supply of permits exceeded the demand wherefore enforcement was never a burning issue. In October 2008 (i.e., during the second trading period, 2008-2012), all national registers were connected to a worldwide UN registry - the International Transaction Log (ITL). To verify the registry transactions, the ITL controls that the trading parties' permit holdings are accurately recorded in the registries. Furthermore, at the end of the second trading period, the ITL will compare the permit holdings of the trading parties with the actual emissions in order to assess if the parties have complied with their emission targets under the Kyoto Protocol. ${ }^{6}$

In sum, available research indicates that inspections have positive effects on compliance with environmental regulations. However, very little information is available on the relative efficiency of different inspection methods, and even less is known about the efficiency of other types of enforcement, such as registry-based enforcement of economic instruments.

\subsection{Behavioural change}

Climate policy, just like environmental policy in general, works largely through influencing other agents to improve their environmental behaviour. This requires an impact both on individuals and on organizations, in particular companies. In order to succeed in influencing the behaviour of individuals and companies, government agencies need to be well-informed about the mechanisms by which such influence can take place.

A fair amount of research has been performed on individual environmental behaviour and how it is influenced by external factors. Education and information are fairly efficient in inducing small, low-cost behavioural changes such as recycling and altered thermostat settings. ${ }^{7}$ Education can also have long-term effects on community norms, with indirect effects on public policies and legislation. However, short-term behavioural changes that incur significant costs on individuals are seldom achieved by education or information alone. Such changes are, however, achievable through measures that change economic incentives (energy efficiency rebates) or make environmentally

\footnotetext{
6 http://unfccc.int/kyoto_protocol/registry_systems/items/2723.php

7 Thaler and Sunstein (2008, p. 194) discuss the example of Southern California Edison, an electricity supplier that wished to encourage its customers to use less energy. Previous attempts to change consumer behaviour through emails and text messages providing information about had proved ineffective. The company therefore gave their customers an "Ambient Orb", i.e., a small ball that glowed red when the customer were using large amounts of energy. Through this information, energy use was reduced by as much as 40 percent in peak periods (see Thompson (2007) for the original discussion of this example).
} 
friendly options more practicable (improved public transportation). Seemingly, successful changes of individual behaviour are often the result of combined strategies, such as information combined with economic incentives rather than information alone or economic incentives alone (Gardner and Stern, 2002).

Up to now, behavioural research relating to the environment has mostly focused on individual behaviour. Much less is known about the mechanisms that influence the environmental behaviour of firms. There are many examples of how companies have yielded to public opinion or political pressure and improved their environmental behaviour. This is how MacDonald's gave up the use of Styrofoam packages, how Dow Chemical Company gave up the production of CFCs, etc. These are cases in which there was a threat of public action leading to economic losses for the companies. Such reactive behaviour will certainly continue to play a role, but in most cases proactive measures can be expected to be more effective, in many cases also more cost-efficient. We need to know under what conditions companies act proactively, without specific pressures from government and the public, to improve their behaviour in terms of climate impact, adaptation, and other environmental issues. The increased role of goal-setting and voluntary agreements in environmental protection has made such research even more imperative.

\subsection{Effects on the environment}

It is one of the major tasks of the environmental (natural) sciences to determine the status of the environment and how it is influenced by changes in social and technological practices. Various sciences, such as epidemiology, public health studies, ecotoxicology, environmental chemistry, and climatology, contribute to this work. The possibilities to determine the effects of environmental policies on the environment are limited in several ways, for instance by statistical variations (Hansson 1999) and by the difficulties involved in drawing conclusions from a few indicator species to the whole ecosystem (Breitholtz et al., 2006).

In the context of climate mitigation, the desired effect can be defined as impact on the earth's mean temperature. The mean temperature can be accurately determined. However, the effects on the mean temperature of reductions of greenhouse gas emissions appear with a considerable time-lag, and the impact of a particular mitigating measure cannot be isolated. Therefore, the effects of mitigation policies cannot be determined empirically but have to be judged from theoretical climate models.

In the context of climate adaptation, the aim is to reduce the negative effects of climate change on social, economic, and ecological systems. Hence, the effects aimed at are not only environmental, but may pertain to various social and economic sectors. For example, some adaptation actions aim at reducing the potential negative health impacts of a warmer climate, such as infectious diseases and heat-related cardiac fatalities. Other actions aim at increasing the resilience of infrastructure, e.g. the resistance of buildings to flooding and other extreme weather events and the capability of climate-depending industries such as the tourism industry to survive under new conditions. The complexity involved in adaptation makes it difficult to measure the success of adaptation policies. It remains to develop a comprehensive goal system for adaptation that can be used to construct operational process- and outcome-based indicators 
on the basis of which the effects of implemented policy measures can be intelligibly assessed.

\subsection{Evaluation}

The term "evaluation" has many usages. ${ }^{8}$ One common distinction is that between evaluations of different types of objects, such as evaluations of the present state in some social sector, evaluations of the effects of a specific intervention (impact evaluation or effect evaluation), evaluations of programmes, etc. Impact evaluations are of special interest in the present context. In particular, it is in this sense that the lack of an evaluation culture in many environmental fields is deplorable; too many measures are decided upon without prior search of information about their efficiency and without evaluation afterwards to find out what effects they did in fact have.

It is important to distinguish between impact evaluation and monitoring. In monitoring, the implementation of a policy instrument and its potential consequences are surveyed, whereas, in an impact evaluation, the aim is to establish the actual consequences caused by the policy instrument (Vedung, 1997). In cases when the effects of a policy are well-known, it may be sufficient to determine to what degree the policy is actually implemented, i.e., monitoring may then in practice give essentially the same information as impact evaluation. Generally speaking, however, impact evaluation is required for policy guidance.

It is also important to distinguish between empirical evaluation and theoretical analysis. In particular the effects from economic instruments have often been more extensively analyzed in theory than in practise (Knaap and Kim, 1998; EEA, 2001; Mickwitz, 2003). Needless to say, although economic theory is indispensible in the development of economic policies, it does not cover all the social complexities of the policies' actual implementation, which makes them as much in need of empirical evaluation as other types of policy instruments (Forslund et al., 2008).

Evaluation of a public authority's activities can be performed by the authority itself, by another government agency, or by non-governmental organizations, such as universities or private consultants. The different types of evaluators differ in their expert knowledge, their independence, and their ability to influence interventions to make them evaluable. For instance, the authority itself possesses great expert knowledge and is able to adjust implementation to make it evaluable, but on the other hand it ranks low in terms of independence. An authority's own evaluations may, therefore, have low credibility. Previous research indicates that the closer the evaluator is to the evaluand, the less prone he is to criticize the evaluand (Statskontoret, 2002). Evaluators too close to the evaluand may find themselves in a precarious situation, not wanting to "bite the hand that feeds them". On the other hand, external evaluators seldom have the opportunity to influence interventions so that adequate control groups are available for a meaningful evaluation. This should at least in principle be easier for internal evaluators.

8 Evaluation is a well-established discipline, both in research and in more directly policy-related work. Since several excellent introductions to the methodology of evaluation are available, no overview of the subject will be given here. The reader is referred to works such as Chen (1990), Pawson and Tilley (1997) and House and Howe (1999) and to the webpages of the major organizations in the field: the European Evaluation Society (www.europeanevaluation.org) and the American Evaluation Association (www.eval.org). 
The lack of a tradition for impact evaluations in public authorities is a problem for many of the measures undertaken or planned in climate mitigation and adaptation. Up to now, few climate-related interventions have been planned from start with the purpose to make them evaluable. However, this is beginning to change as governments are increasingly making use of climate change policy reviews to inform the decisionmaking process. For example, in the UK the results of an effort to evaluate the policies in the 2000 Climate Change Programme (CCP) are now being taken into consideration in the Government's work on climate change (Defra 2006, www.decc.gov.uk). In 2005, a similar climate change policy review was conducted in New Zealand (Ministry for the Environment 2005, www.mfe.govt.nz).

\section{Conclusions}

We propose that the policy cycle, as shown in Figure 4, be used as a framework for improving the efficiency of public environmental policy instruments, in particular in the complex tasks of climate mitigation and adaptation. Our discussion of the six elements of the cycle has shown that there are large and varied research needs that have to be addressed in order to better understand how environmental policies, including climate policies, can be made more efficient, such as the following:

- Analyses of environmental goal systems and how they influence (or fail to influence) actual environmental action.

- Comparative studies of the efficiency of different policy instruments, such as economic instruments, regulation, voluntary agreements, and information.

- Studies of how the effects of regulations depend on different variables in regulation, such as the level of generality.

- Studies of the efficiency of inspections and of different inspection methods.

- Studies of the enforcement and evaluation of economic instruments.

- Studies of how the environmental behaviour of businesses can be influenced in the direction of environmental responsibility.

- Studies of the combined effects of scientific uncertainty about environmental effects and uncertainty about the effects of policy instruments.

- Studies of the factors that can promote the use of impact evaluations in public agencies. 


\section{References}

Bailey, I. (2008) "Industry Environmental Agreements and Climate Policy: Learning by Comparison", Journal of Environmental Policy and Planning 10(2): 153-173.

Baranzini, A. and P. Thalmann (Eds.) (2004) Voluntary Approaches in Climate Policy. Edward Elgar: Cheltenham.

Barker, T., Bashmakov, I., Alharthi, A., Amann, M., Cifuentes, L., Drexhage, J., Duan,M., Edenhofer, O., Flannery, B., Grubb, M., Hoogwijk, M., Ibitoye, F. I., Jepma, C. J., Pizer, W. A. and K. Yamaji (2007) "Mitigation from a cross-sectoral perspective", pp. 619-690 in Metz, B., Davidson, O. R., Bosch, P. R., Dave, R. and L.A. Meyer (Eds.) Climate Change 2007: Mitigation. Contribution of Working Group III to the Fourth Assessment Report of the Intergovernmental Panel on Climate Change. Cambridge University Press, Cambridge and New York.

Baumol, W. J. and W. E. Oates (1988) The Theory of Environmental Policy. Second edition. Cambridge University Press: Cambridge.

Björkdahl, C., Wester-Herber, M. and S. O. Hansson (2008) "Effects of Workplace Inspections - The Swedish Noise Campaign", Policy and Practice in Health and Safety 6:55-63.

Bovenberg, A. L. (1999) "Green Tax Reform and the Double Dividend: an Updated Reader's Guide", International Tax and Public Finance 6:421-443.

Bovenberg, A. L. and L. H. Goulder, (1996) "Optimal Environmental Taxation in the Presence of Other Taxes: General-Equilibrium Analyses", The American Economic Review 86 (4): 985-1000.

Breitholtz, M., Rudén, C., Hansson, S. O. and B. E. Bengtsson (2006) "Ten Challenges for Improved Ecotoxicological Testing in Environmental Risk Assessment", Ecotoxicology and Environmental Safety 63:324-335.

Börkey, P. and F. Lévêque (2000) "Voluntary Approaches for Environmental Protection in the European Union: A Survey", European Environment 10: 35-54.

Chen, H. -T. (1990) Theory-Driven Evaluations. Sage Publications: Newbury Park, California.

Carroll, S. J. and H. L. Tosi (1973) Management by Objectives: Applications and Research. New York: MacMillan.

Coffman, J. (2002) Public Communication Campaign Evaluation. An Environmental Scan of Challenges, Criticisms, Practice, and Opportunities. Communications Consortium, Media Center, Washington DC.

Corfee-Morlot, J. and N. Höhne (2003) "Climate Change: Long-term Targets and Short-term Commitments", Global Environmental Change 13: 277-293.

Croci, E. (2003) "Voluntary Agreements for $\mathrm{CO}_{2}$ Emissions Reduction: Evaluation and Perspectives", Energy and Environment 14: 663-676.

Croci, E. (2005) The Handbook of Environmental Voluntary Agreements: Design, Implementation and Evaluation Issues. Springer: Dordrecht. Davies, N. and Z. Makuch (2009) "UK Climate Change Agreements: An Evaluation of Performance to Date and Options for the Future", European Energy and Environmental Law Review XXX: 19-33.

de Jong, F. (1998) "Marine Ecological Quality Objectives: Science and Management Aspects", in: Müller, F. And M. Leupelt (Eds.) Eco Targets, Goal Functions, and Orientors. Berlin and Heidelberg: SpringerVerlag.

Department for Environment, Food and Rural Affairs (DEFRA) (2006) Synthesis of Climate Change Policy Evaluations. Defra: London.

Dijkstra, B. R. (1998) The Political Economy of Instrument Choice in Environmental Policy. Groningen University: Groningen, The Netherlands.

Directive 2003/87/EC of the European Parliament and of the Council of 13 October 2003 establishing a scheme for greenhouse gas emission allowance trading within the Community and amending Council Directive 96/61/EC, Official Journal L 275, 25/10/2003 P. 0032 - 0046.

Drottz-Sjöberg, B. -M. (1993) "Risk Perceptions Related to Varied Frames of Reference", in: Hubert, P. and M. Poumadere (Eds.) Proceedings of the Third Conference of Society for Risk. Analysis Europe, 1991, European Section of the Society for Risk Analysis: Paris, pp. 55-66.

Eckert H. (2004) "Inspections, Warnings, and Compliance: the Case of Petroleum Storage Regulation", Journal of Environmental Economics and Management 47:232-259. 
Edvardsson, K. and S. O. Hansson (2005) "When Is A Goal Rational?", Social Choice and Welfare 24(2): 343-361.

Edvardsson Björnberg, K. and Å. Svenfelt (2009) Goal Conflicts in Adaptation to Climate Change. Report No. FOI-R-2747-SE. Swedish Defence Research Agency: Stockholm. Available at: http://www.foi.se/upload/FOI-R--2747--SE\%20Goal\%20conflicts.3.pdf (accessed on 6 April 2011).

Edvardsson Björnberg, K. and S. O. Hansson (in press) "Five Areas of Value Judgement in Local Adaptation to Climate Change. Forthcoming in Local Government Studies.

EEA (European Environmental Agency) (2001) Reporting on Environmental Measures: Are We Being Effective? Environmental Issue Report No 25, European Environmental Agency: Copenhagen.

EEA (European Environmental Agency) Glossary (2011). http://glossary.eea.europa.eu/. Accessed 201105-03.

European Commission (2009) Draft Commission Regulation Implementing Directive 2005/32/EC of the European Parliament and of the Council with regard to ecodesign requirement for non-directional household lamps. http://ec.europa.eu/energy/efficiency/ecodesign/regulatory_committee_en.htm

Forslund, J., Samakovlis, E. and M. Vredin Johansson (2008) "Is it Wise to Combine Environmental and Labour Market Policies? An Analysis of a Swedish Subsidy Programme”, Ecological Economics 65:547558.

Gabrielsen, P. and P. Bosch (2003) "Environmental Indicators: Typology and Use in Reporting" EEA Internal Working Paper, European Environmental Agency.

Gardner, G. T. and P. C. Stern (2002) Environmental Problems and Human Behavior. Second edition. Pearson Custom Publishing: Boston.

Glachant, M. (1999). "The Efficiency of Policy Instruments for Regulating Industrial Pollutio: A Coasean Approach", in: Carraro, C. and F. Lévêque (Eds.) Voluntary Approaches in Environmental Policy, Kluwer Academic, Dordrecht, pp. 56-75

Goodstein, E. (2003) “ The Death of the Pigouvian Tax? Policy Implications from the Double-Dividend Debate". Land Economics 79 (3): 402-414.

Goulder, L. H. (1998) "Environmental Policy Making in a Second-Best Setting", Journal of Applied Economics 1 (2): 279-328.

Goulder, L. H., Parry, I. W. H., Williams III, R. C. and D. Burtraw (1999) “The Cost-Effectiveness of Alternative Instruments for Environmental Protection in a Second-Best Setting". Journal of Public Economics 72:329-360.

Gray, W. B. and M. E. Deily (1996) "Compliance and Enforcement: Air Pollution Regulation in the U.S. Steel Industry", Journal of Environmental Economics and Management, 31:96-111.

Gray, W. B. and C.A. Jones (1991a) "Are OSHA Health Inspections Effective? A Longitudinal Study in the Manufacturing Area", Review of Economics and Statistics 73:504-508.

Gray, W. B. and C. A. Jones (1991b) "Longitudinal Patterns of Compliance with Occupational Safety and Health Administration. Health and Safety Regulations in the Manufacturing Sector", Joumal of Human Resources 26:622-653.

Gray, W. B. and J. T. Scholz (1993) "Does Regulatory Enforcement Work? A Panel Analysis of OSHA Enforcement", Law and Society Review 27:177-213.

Gupta, S., Tirpak, D. A., Burger, N., Gupta, J., Höhne, N., Boncheva, A. I., Kanoan, G. M., Kolstad, C., Kruger, J. A., Michaelowa, A., Murase, S., Pershing, J., Saijo, T. and A. Sari (2007) "Policies, Instruments and Co-operative Arrangements", in: B. Metz, O.R. Davidson, P.R. Bosch, R. Dave, L.A. Meyer (eds) Climate Change 2007: Mitigation. Contribution of Working Group III to the Fourth Assessment Report of the Intergovernmental Panel on Climate Change, Cambridge University Press, Cambridge, United Kingdom and New York, NY, USA, pp. 745-807.

Hall, H. K. and A. W. Kerr (2001) "Goal Setting in Sport and Physical Activity: Tracing Empirical Developments and Establishing Conceptual Direction", in: Roberts, G. C. (Ed.) Advances in Motivation in Sport and Exercise. Champaign, Ill.: Human Kinetics, pp. 183-233.

Hamin, E. M. and N. Gurran (2009) "Urban Form and Climate Change: Balancing Adaptation and Mitigation in the U.S. and Australia", Habitat International 33: 238-245.

Hanley N., Shogren, J. F. and B. White (1997) Environmental Economics: In Theory and Practice. Oxford University Press: Oxford.

Hansson, S. O. (1998) Setting the Limit. Occupational Health Standards and the Limits of Science. Oxford University Press: Oxford. 
Hansson, S. O. (1999) “The Moral Significance of Indetectable Effects”, Risk 10: 101-108.

Hansson, S. O. (2003) “Ten Philosophical Problems in Belief Revision”, Journal of Logic and Computation 13: 37-49.

Hansson, S. O. (2007a) "Philosophical Problems in Cost-Benefit Analysis", Economics and Philosophy 23: 163-183.

Hansson, S. O. (2007b) "Praxis Relevance in Science", Foundations of Science 12: 139-154.

Health Canada (2008) Human Health in a Changing Climate: A Canadian Assessment of Vulnerabilities and Adaptive Capacity. Health Canada: Ottawa, Ontario.

Horrocks, L., Mayhew, J., Watkiss, P., Hunt, A. and T. Downing (2005) Objective Setting for Climate Change Adaptation Policy. Report prepared by AEA Technology Environment, Stockholm Environment Institute and Metroeconomica. Available at: http://www.ukcip.org.uk/wordpress/wpcontent/PDFs/Objective_setting.pdf (accessed 6 April 2011).

Horst, D. P., McCarthy, G. E., Robinson, J. N., McCarthy, R. L. and S. Krumm-Scott ([1986] 1994) "Safety Information Presentation: Factors Influencing the Potential for Changing Behavior", in: Laughery, K. R., Wogalter, M. S. and S. L. Young (Eds.) Human Factors Perspectives on Warnings: Selections from Human Factors and Ergonomics Society Annual Meetings, 1980-1993, Human Factors and Ergonomics Society, 1994, pp. 86-90.

House, E. R. and K. R. Howe (Eds.) (1999) Values in Evaluation and Social Research, Thousand Oaks: California.

IPCC (Intergovernmental Panel on Climate Change) TAR 2001 Climate Change 2001: Impacts, Adaptation, and Vulnerability. Contribution of Working Group II to the Third Assessment Report (TAR) of the Intergovernmental Panel on Climate Change. McCarthy, J. J., Canziani, O. F., Leary N. A., Dokken, D. J. and White, K. S. (Eds.). Cambridge University Press: Cambridge.

Jaeger, W. K. (2004) “Optimal Environmental Taxation from Society’s Perspective” American Journal of Agricultural Economics 86 (3): 805-812.

Johnston, R., Fitzgerald, L., Markou, E. and S. Brignall (2001) 'Target Setting for Evolutionary and Revolutionary Process Change", International Journal of Operations and Production Management 21(11): 1387-1403.

Kahneman D. and A. Tversky (1979) "Prospect Theory: An Analysis of Decision under Risk", Econometrica 47:263-291.

Klein, R. J. T., Huq, S., Denton, F., Downing, T. E., Richels, R. G., Robinson, J. B. and F. L. Toth (2007) "Inter-relationships between Adaptation and Mitigation", pp. 745-777 in Parry, M. L., Canziani, O. F., Palutikof, J. P., van der Linden, P. J. and C. E. Hanson (Eds.) Climate Change 2007: Impacts, Adaptation and Vulnerability. Contribution of Working Group II to the Fourth Assessment Report of the Intergovernmental Panel on Climate Change. Cambridge University Press: Cambridge.

Knaap, G. J. and T. J. Kim (1998) "Environmental Program Evaluation: Framing the Subject, Identifying Issues”, in: Knaap, G. J. and T. J. Kim (Eds) Environmental Program Evaluation. A Primer. University of Illinois Press: Urbana and Chicago.

Laplante B. and P. Rilstone (1996) "Environmental Inspections and Emissions of the Pulp and Paper Industry in Quebec", Journal of Environmental Economics and Management 31:19-36.

Latham, G. P. (2003) "Goal Setting: A Five-Step Approach to Behaviour Change”, Organizational Dynamics 32(3): 309-318.

Le Grand, J. (1990) “Equity versus Efficiency: The Elusive Trade-off”, Ethics 100:554-568.

Le Grand, J. (1991) Equity and Choice. An Essay in Economics and Applied Philosophy. Harper Collins Academic: London.

Lehto, M. R. and J. M. Miller (1986) Warnings. Volume 1: Fundamentals, Designs, and Evaluation Methodologies. Fuller Technical Publications: Ann Arbor, MI.

Lindblom, L. and S. O. Hansson (2004) "Evaluating Workplace Inspections", Policy and Practice in Health and Safety 2(2): 77-91.

Lipsky, M. (1980) Street-Level Bureaucracy - Dilemmas of the Individual in Public Services. Russel Sage Foundation: New York.

Locke, E. A. and G. P. Latham (1990) A Theory of Goal Setting and Task Performance. Englewood Cliffs, New Jersey: Prentice Hall.

Mc Evoy, D., Lindley, S. and J. Handley (2006) "Adaptation and Mitigation in Urban Areas: Synergies and Conflicts", Municipal Engineer 159: 185-191. 
Magat, W. A. and W. K. Viscusi (1990) “Effectiveness of the EPA's Regulatory Enforcement: The Case of Industrial Effluent Standards", Journal of Law and Economics 33:331-360.

Maxim, L., Spangenberg, J. H. and M. O'Connor (2009) "An Analysis of Risks for Biodiversity under the DPSIR Framework". Ecological Economics 69:12-23.

Mickwitz, P. (2003) “A Framework for Evaluating Environmental Policy Instruments. Context and Key Concepts", Evaluation 9(3):415-436.

Ministry for the Environment (2005) Review of Climate Change Policies. 2 November 2005. http://www.mfe.govt.nz/publications/climate/policy-review-05/policy-review-05.pdf

Mintzberg, H., Raisinghani, D. and A. Théorêt (1976) “The Structure of 'Unstructured' Decision Processes", Administrative Sciences Quarterly 21:246-275.

OECD (1998) Voluntary Approaches for Environmental Policy in OECD Countries: An Assessment. < http:/ /www.cerna.ensmp.fr/Documents/PBMGFL-OECDVAs.pdf

OECD (2003) Voluntary Approaches for Environmental Policy: Effectiveness, Efficiency and Usage in Policy Mixes. OECD: Paris.

OECD (2008) Economic Aspects of Adaptation to Climate Change. Costs, Benefits and Policy Instruments. Edited by Agrawala, S. and S. Frankhauser. OECD Publishing.

Odiorne, G. S. (1969) Management Decisions by Objectives. Englewood Cliffs, N.J.: Prentice Hall.

Oppenheimer, M. (2005) "Defining Dangerous Anthropogenic Interference: The Role of Science, the Limits of Science", Risk Analysis 25(6): 1399-1407.

Oppenheimer, M. and A. Petsonk. (2005) "Article 2 of the UNFCCC: Historical Origins, Recent Interpretations", Climatic Change 73: 195-226.

Pawson, R. and N. Tilley (1997) Realistic Evaluation. Sage: London.

Pershing, J. and F. Tudela (2003) "A Long-Term Target: Framing the Climate Effort", pp. 11-36 in Aldy, J. E. et al. Beyond Kyoto: Advancing the International Effort against Climate Change. Pew Center on Global Climate Change.

Peterson, T. D. and A. Z. Rose (2006) "Reducing Conflicts between Climate Policy and Energy Policy in the US: The Important Role of the States", Energy Policy 34: 619-631.

Philibert, C. and J. Pershing (2001) "Considering the Options: Climate Targets for All Countries", Climate Policy 1: 211-227.

Quinn, J. B. (1977) "Strategic Goals: Process and Politics", Sloan Management Review 19: 21-37.

Schelling, T. (1995) "Intergenerational Discounting”, Energy Policy, 23(4/5): 395-401.

Scholz, J. T. and W. B. Gray (1990) "OSHA Enforcement and Workplace Injuries: A Behavioral Approach to Risk Assessment", Journal of Risk and Uncertainty 3:283-305.

Sjöberg, L. and B. -M. Drottz-Sjöberg (1998) “Hur upplever vi teknikens risker?”, in: Grimvall, G., Jacobsson, P. and T. Thedèen (Eds.) Risker i tekniska system. Utbildningsradion: Stockholm.

Slocombe, D.S. (1998) "Defining Goals and Criteria for Ecosystem-based Management", Environmental Management 22(4): 483-493.

Slovic, P., Fischhoff, B. and S. Lichtenstein (1979) "Rating the Risks", Environment 21:14-20, 36-39.

Slovic, P., Fischhoff, B. and S. Lichtenstein (1980) "Facts and Fears: Understanding Perceived Risk", in: Schwing, R. C. and W. A. Albers Jr. (Eds.) Societal Risk Assessment. Plenum Press: New York, pp. 181-216.

Smeets, E. and R. Weterings (1999) "Environmental Indicators: Typology and Overview" Technical Report No 25, European Environmental Agency.

Statskontoret (2002) Utvärderingar - Av vem till vad? En kartläggning av Regeringskansliets utvärderingsresurser. Report 2002:20. Statskontoret: Stockholm.

Stavins, R. N. (2003) “Experience with Market-Based Environmental Policy Instruments”, in: Mäler, K-G. and J. R. Vincent (Eds.) Handbook of Environmental Economics. Volume 1: Environmental Degradation and Institutional Responses. Elsevier, Amsterdam.

Stead, D. (1997) “Environmental Targets in Land-use Planning”, in: Farthing, S. M. (Ed.) Evaluating Local Environmental Policy. Ashgate Publishing: Aldershot.

Stern, N. (2008) "The Economics of Climate Change", American Economic Review 98(2): 1-37.

Swedish Commission on Climate and Vulnerability (2007) Sweden Facing Climate Change - Threats and Opportunities. Final Report from the Swedish Commission on Climate and Vulnerability. Swedish Government Official Reports, SOU 2007:60. Stockholm: Fritze.Thalmann, P. and A. Baranzini (2004) "An Overview of the Economics of Voluntary Approaches in Climate Policies", pp. 1-30 in Baranzini, 
A. and P. Thalmann (Eds.) Voluntary Approaches in Climate Policy. Edward Elgar Publishing: Cheltenham and Northamption, MA.

Thaler, R. H. and C. R. Sunstein (2008) Nudge: Improving Decisions about Health, Wealth, and Happiness. Yale University Press: New Haven and London.

Thompson, C. (2007) "Desktop Orb Could Reform Energy Hogs", Wired Magarine, Issue 15.08. Published online 24/07/2007.

Tietenberg, T. (2002) "The Tradable Permits Approach to Protecting the Commons: What Have We Learned?” Fondazione Eni Enrico Mattei (FEEM) working paper, Nota di Lavoro 36.2002 http://papers.ssrn.com/sol3/papers.cfm?abstract_id=315500.

Tinggaard Svendsen, G. and M. Vesterdal (2003) "How to Design Greenhouse Gas Trading in the EU?", Energy Policy 31(14):1531-1539.

Tol, R. S. J. (2005a) “Adaptation and Mitigation: Trade-Offs in Substance and Methods", Environmental Science and Policy 8: 572-578.

Tol, R. S. J. (2005b) "Emission Abatement versus Development As Strategies to Reduce Vulnerability to Climate Change", Environment and Development Economics 10: 615-629.

van Herten, L. M. and L. J. Gunning-Shepers (2000) "Targets as a Tool in Health Policy Part I: Lessons Learned", Health Policy 52: 1-11.

Vedung E. (1997) Public Policy and Program Evaluation. Transaction Publishers: New Brunswick.

Weil, D. (1996) "If OSHA Is So Bad, Why is Compliance So Good?", RAND Journal of Economics 27:618640.

Weitzman, M. L. (1974) "Prices vs. Quantities", Review of Economic Studies 41:477-491.

Wogalter, M. S., Godfrey, S. S., Fontenelle, G. A., Desaulniers, D. R., Rothstein, P. and K. R. Laughery (1987) "Effectiveness of Warnings", Human Factors 29:599-612. 


\section{Titles in Working Paper Series/Specialstudier}

Tidigare publicerade Working Paper finns på www.konj.se

\begin{tabular}{|c|c|c|c|}
\hline No & Author & Title & Year \\
\hline 101 & Östblom, Göran & $\begin{array}{l}\text { Nitrogen and Sulphur Outcomes of a Carbon Emis- } \\
\text { sions Target Excluding Traded Allowances - } \\
\text { An Input-Output Analysis of the Swedish Case }\end{array}$ & 2007 \\
\hline 102 & $\begin{array}{l}\text { Hammar, Henrik and } \\
\text { Åsa Löfgren }\end{array}$ & $\begin{array}{l}\text { Explaining adoption of end of pipe solutions and } \\
\text { clean technologies - Determinants of firms' invest- } \\
\text { ments for reducing emissions to air in four sextors in } \\
\text { Sweden }\end{array}$ & 2007 \\
\hline 103 & $\begin{array}{l}\text { Östblom, Göran and } \\
\text { Henrik Hammar }\end{array}$ & $\begin{array}{l}\text { Outcomes of a Swedish Kilometre Tax. An Analysis } \\
\text { of Economic Effects and Effects on NOx Emissions }\end{array}$ & 2007 \\
\hline 104 & $\begin{array}{l}\text { Forsfält, Tomas, } \\
\text { Johnny Nilsson and } \\
\text { Juhana Vartianinen }\end{array}$ & $\begin{array}{l}\text { Modellansatser i Konjunkturinstitutets medelfrist- } \\
\text { prognoser }\end{array}$ & 2008 \\
\hline 105 & Samakovlis, Eva & $\begin{array}{l}\text { How are Green National Accounts Produced in Prac- } \\
\text { tice? }\end{array}$ & 2008 \\
\hline 106 & $\begin{array}{l}\text { Markowski, Alek, } \\
\text { Kristian Nilsson and } \\
\text { Marcus Widén }\end{array}$ & $\begin{array}{l}\text { Strukturell utveckling av arbetskostnad och priser i } \\
\text { den svenska ekonomin }\end{array}$ & 2011 \\
\hline 107 & $\begin{array}{l}\text { Forslund, Johanna, } \\
\text { Per Johansson, Eva } \\
\text { Samakovlis and Maria } \\
\text { Vredin Johansson }\end{array}$ & $\begin{array}{l}\text { Can we by time? Evaluation. Evaluation of the } \\
\text { government's directed grant to remediation in Sweden }\end{array}$ & 2009 \\
\hline 108 & $\begin{array}{l}\text { Forslund, Johanna } \\
\text { Eva Samakovlis, Maria } \\
\text { Vredin Johansson and } \\
\text { Lars Barregård }\end{array}$ & $\begin{array}{l}\text { Does Remediation Save Lives? } \\
\text { On the Cost of Cleaning Up } \\
\text { Arsenic-Contaminated } \\
\text { Sites in Sweden }\end{array}$ & 2009 \\
\hline 109 & $\begin{array}{l}\text { Sjöström, Magnus and } \\
\text { Göran Östblom }\end{array}$ & $\begin{array}{l}\text { Future Waste Scenarios for Sweden on the Basis of a } \\
\text { CGE-model }\end{array}$ & 2009 \\
\hline 110 & Österholm, Pär & $\begin{array}{l}\text { The Effect on the Swedish Real Economy of the Fi- } \\
\text { nancial Crisis }\end{array}$ & 2009 \\
\hline 111 & Forsfält, Tomas & $\begin{array}{l}\text { KIMOD } 2.0 \text { Documentation of changes in the model } \\
\text { from January } 2007 \text { to January } 2009\end{array}$ & 2009 \\
\hline 112 & Österholm, Pär & $\begin{array}{l}\text { Improving Unemployment Rate Forecasts Using } \\
\text { Survey Data }\end{array}$ & 2009 \\
\hline 113 & Österholm, Pär & $\begin{array}{l}\text { Unemployment and Labour-Force } \\
\text { Participation in Sweden }\end{array}$ & 2009 \\
\hline 114 & $\begin{array}{l}\text { Jonsson, Thomas and } \\
\text { Pär Österholm }\end{array}$ & $\begin{array}{l}\text { The Properties of Survey-Based } \\
\text { Inflation Expectations in Sweden }\end{array}$ & 2009 \\
\hline 115 & $\begin{array}{l}\text { Hjelm, Göran and } \\
\text { Kristian Jönsson }\end{array}$ & $\begin{array}{l}\text { In Search of a Method for Measuring the Output Gap } \\
\text { of the Swedish Economy }\end{array}$ & 2010 \\
\hline 116 & Vartiainen, Juhana & Interpreting Wage Bargaining Norms & 2010 \\
\hline 117 & $\begin{array}{l}\text { Mossfeldt, Marcus and } \\
\text { Pär Österholm }\end{array}$ & $\begin{array}{l}\text { The Persistent Labour-Market Effects of the Financial } \\
\text { Crisis }\end{array}$ & 2010 \\
\hline 118 & $\begin{array}{l}\text { Östblom, Göran, Ma- } \\
\text { ria Ljunggren Söder- } \\
\text { man and Magnus Sjö- } \\
\text { ström }\end{array}$ & $\begin{array}{l}\text { Analysing future solid waste generation - Soft linking } \\
\text { a model of waste management with a CGE-model for } \\
\text { Sweden }\end{array}$ & 2010 \\
\hline
\end{tabular}




\begin{tabular}{|c|c|c|c|}
\hline 119 & $\begin{array}{l}\text { Broberg, Thomas, } \\
\text { Per-Olov Marklund, } \\
\text { Eva Samakovlisa and } \\
\text { Henrik Hammar }\end{array}$ & $\begin{array}{l}\text { Does environmental leadership pay off for Swed-ish } \\
\text { industry? - Analyzing the effects of environ-mental } \\
\text { investments on efficiency }\end{array}$ & 2010 \\
\hline 120 & $\begin{array}{l}\text { Gustavsson, Magnus } \\
\text { and Pär Österholm }\end{array}$ & $\begin{array}{l}\text { Labor-Force Participation Rates and the } \\
\text { Informational Value of Unemployment Rates: Evi- } \\
\text { dence from Disaggregated US Data }\end{array}$ & 2010 \\
\hline 121 & $\begin{array}{l}\text { Jonsson, Thomas and } \\
\text { Pär österholm }\end{array}$ & $\begin{array}{l}\text { The Forecasting Properties of Survey-Based Wage- } \\
\text { Growth Expectations }\end{array}$ & 2010 \\
\hline 122 & $\begin{array}{l}\text { Antipin, Jan-Erik, } \\
\text { Jimmy Boumediene } \\
\text { and Pär Österholm }\end{array}$ & $\begin{array}{l}\text { On the Usefulness of Constant Gain Least Squares } \\
\text { when Forecasting the Unemployment Rate }\end{array}$ & 2011 \\
\hline 123 & $\begin{array}{l}\text { Broberg, Thomas, } \\
\text { Tomas Forsfält and } \\
\text { Göran Östblom }\end{array}$ & $\begin{array}{l}\text { The Excess Cost of Supplementary Constraints in } \\
\text { Climate Policy: The Case of Sweden's Energy Inten- } \\
\text { sity Target }\end{array}$ & 2011 \\
\hline 124 & $\begin{array}{l}\text { Baard, Patrik, Henrik } \\
\text { Carlsen, Karin Ed- } \\
\text { vardsson Björnberg } \\
\text { and Maria Vredin } \\
\text { Johansson }\end{array}$ & $\begin{array}{l}\text { Scenarios and Sustainability. A Swedish Case Study of } \\
\text { Adaptation Tools for Local Decision-Makers }\end{array}$ & 2011 \\
\hline
\end{tabular}

